\title{
The Effect of Bankruptcy on U.S. Air Fares
}

\author{
Ray R. Sturm \\ Department of Finance \\ College of Business Administration \\ University of Central Florida, USA \\ 600 Colonial Center Parkway \\ Lake Mary, Florida 32746
}

Tel: 1-407-531-5461Ｅ-mail: Rsturm@mail.ucf.edu

\author{
Drew B. Winters (Corresponding author) \\ Lucille and Raymond Pickering Chair in Finance \\ Rawls College of Business Administration, USA \\ Department of Finance \\ Box 42101 \\ Lubbock, TX 79409-2101 \\ Tel: 1-806-742-3350Ｅ-mail: Drew.Winters@TTU.edu
}

\begin{abstract}
Borenstein and Rose (1995) find that bankruptcy filing per se does not substantially affect the pricing behavior of the bankrupt carrier. In September 2005, Delta entered bankruptcy and USAir emerged from bankruptcy. We follow Borenstein and Rose (1995) by collecting daily data on air fares for Delta, Southwest and USAir airlines around these events. We find that financially healthy airlines (Southwest in this study) apparently do not respond to bankruptcy events, which is counter to the findings in Borenstein and Rose (1995). We also find that airlines entering bankruptcy (Delta in this study) do not change their pricing strategy in the near-term around the bankruptcy filing and airlines exiting bankruptcy (USAir in this study) price their tickets aggressively.
\end{abstract}

Keywords: Airlines, Bankruptcy, Pricing 


\section{Introduction}

The airline industry has a rich history of financial distress and of seeking the protection benefits of filing for bankruptcy. For example, seven major carriers sought Chapter 11 bankruptcy protection between 2001 and 2005 (see, Hofer et. al. (2009)). Therefore, the airline industry is an ideal setting in which to study a firm's pricing behavior around times of bankruptcy.

The effect of financial distress on pricing has a substantial body of literature. Hofer, Dresner and Windle (2009) provide an excellent review of the literature in which they cite that on average, many studies find that financially-distressed firms will sell their products at lower prices. The extant literature on the airline industry is consistent with the general finding that financially-distressed firms lower their price. In this study, we move from the effect of financial distress to focus just on the impact of bankruptcy on airlines. Borenstein and Rose (1995) find no change in airline prices when filing for bankruptcy. We re-examine the findings in Borenstein and Rose (1995) and extend the analysis to include airlines emerging from bankruptcy protection. Specifically, we examine the concurrent pricing behavior of three airlines - one that is entering bankruptcy, one that is emerging from bankruptcy, and one that is financially stable - in the fall of 2005.

We collect data on airfares for Southwest, Delta and USAir around the bankruptcy events for Delta (filing for) and USAir (emerging from) in September 2005. We find that Southwest prices increase across the sample period, but the prices paid for jet fuel also increase across the sample period suggesting that Southwest's price increase is more likely related to cost increases than a response to Delta's bankruptcy. Delta does not appear to change its pricing in the near-term around its bankruptcy filing. However, after emerging from bankruptcy USAir more aggressively prices its tickets than either Southwest or Delta suggesting that it is attempting to capture market share.

\section{Literature/Theory}

Several studies have examined the impact of bankruptcy on a firm's pricing. This study is focused on the airline industry, but is not the first to study the relation between air fares and financial distress in this industry. For example, in a 1995 paper in the American Economic Review, Borenstein and Rose examine the impact of bankruptcy announcements by large U.S. carriers on airline pricing behavior. They find that bankruptcy filing per se does not substantially affect the pricing behavior of the bankrupt carrier, although lower prices are associated with the financial distress leading up to the bankruptcy. Further, they find that competitors of the bankrupt carrier tend to raise prices in the quarter that the bankruptcy was filed.

Busse (2002) studies 14 major airlines over the period 1985 - 1992, and finds a positive relation between financial distress and the likelihood of starting a price war. That is, the worse the airline's financial condition, the more likely that airline is to start a price war particularly for highly-levered airlines. In addition, the greater the competitor's market share, the greater the likelihood that the competitor will enter the price war. 
More recently, Hofer, Dresner and Windle (2009) study the circumstances under which financial distress will impact a firm's pricing behavior. Using data from 1992-2002 on the top 1,000 U.S. domestic route origin and destination route markets, they find a negative relation between financial distress and air fares. Moreover, they find that the magnitude of the effect decreases with the magnitude of operating costs and the firm's market share, and increases with firm size and the level of market concentration. These findings are consistent with their 2005 study (Hofer, et al., 2005) in which they find that the air fares of distressed airlines tends to be lower than those of their healthier competitors. They also find that bankrupt carries, on average, charge about 7.2\% less than non-bankrupt carriers.

We contribute to the existing literature of bankruptcy and airlines by examining two empirical questions. First, Borenstein and Rose (1995) find evidence that bankrupt airlines do not change their prices and competitors either maintain or increase their prices. These results suggest: (1) that the bankrupt airlines view themselves as going concerns with their tickets remaining a substitute for the tickets of other airlines and (2) that the competitors of the bankrupt airline feel that competition has declined allowing for the increase in their prices. Clearly, both sides cannot be correct. Accordingly, we re-visit this empirical issue.

Second, the existing empirical evidence suggests frequent price wars when an airline becomes financially distressed. Price wars suggest that airlines fight for market share when they are in financial distress presumably because they are losing market share. An interesting empirical question is how do airlines price their tickets when they exit financial distress. Exiting financial distress is likely difficult to identify. However, emerging from bankruptcy is not difficult to identify. Studies have examined the stock performance and financial performance of firms emerging from bankruptcy (see Eberhart et al. (1999), Alderson and Betker (1999) and others). However, examining pricing in general and airline ticket prices in particular has not been addressed to the best of our knowledge. Airlines emerging from bankruptcy can signal their reduced financial distress and should be in improved position to fight for market share. (Note 1) Whether they aggressively price their tickets is an empirical question that we examine. If an airline emerging from bankruptcy does reduce its ticket prices, then an additional empirical issue of interest is whether competitors respond by lowering their prices.

\section{Data and Methodology}

Our sample includes non-refundable airline ticket prices from July 1, 2005 through November 30, 2005. The data for Delta and Southwest ticket prices from July 1, 2005 through September 30, 2005 were collected for a different study, so this portion of the sample is best described as a sample of convenience. When USAir emerged from bankruptcy shortly after Delta filed for bankruptcy, we took the opportunity to extend the sample on Delta and Southwest through November 30, 2005 and collect USAir prices from September 21, 2005 through November 30, 2005. Because historical data are not readily available, we hand-collect ticket prices from the websites of each airline daily on a real-time basis. Accordingly, we cannot back-fill data before the beginning of the original convenience sample. We chose to end the data on November 30, 2005 because the holiday season may 


\section{Macrothink Institute ${ }^{\text {TM }}$}

not represent normal ticket price behavior and non-refundable ticket prices are collected because the put option component of refundable ticket prices can confound the true ticket price behavior (Sturm and Winters (2009)). Finally, we collect ticket prices for 7-, 30- and 120-day advanced booking periods to control for behavior related to advanced booking time.

Price data from Southwest was chosen as a benchmark because Southwest is the most financially stable and successful airline in the history of U.S. airlines. Delta and USAir ticket prices are test samples. Thus, we have test samples of one airline entering bankruptcy and one emerging from bankruptcy with a financially stable airline serving as a benchmark.

\section{Results and Discussion}

We use price data from Southwest, Delta, and USAir from each airline's hub city to Chicago and Orlando. Clearly, flights originating from different cities are not substitutes so we cannot directly compare prices. Instead, we use Southwest as the baseline of a financially healthy airline and examine the changes in prices of the other two airlines relative to Southwest's price behavior over the same period to the same locations.

Figures 1 - 3 and Table 1 present the average ticket prices for the Chicago route of all three carriers over three advanced booking time periods. This data set is adjusted for outliers in order to approximate normal price behavior. The adjustment was necessary because of a few data points that appeared out of character. As such, we considered them to likely be the result of a bad quote rather than representative of price behavior.

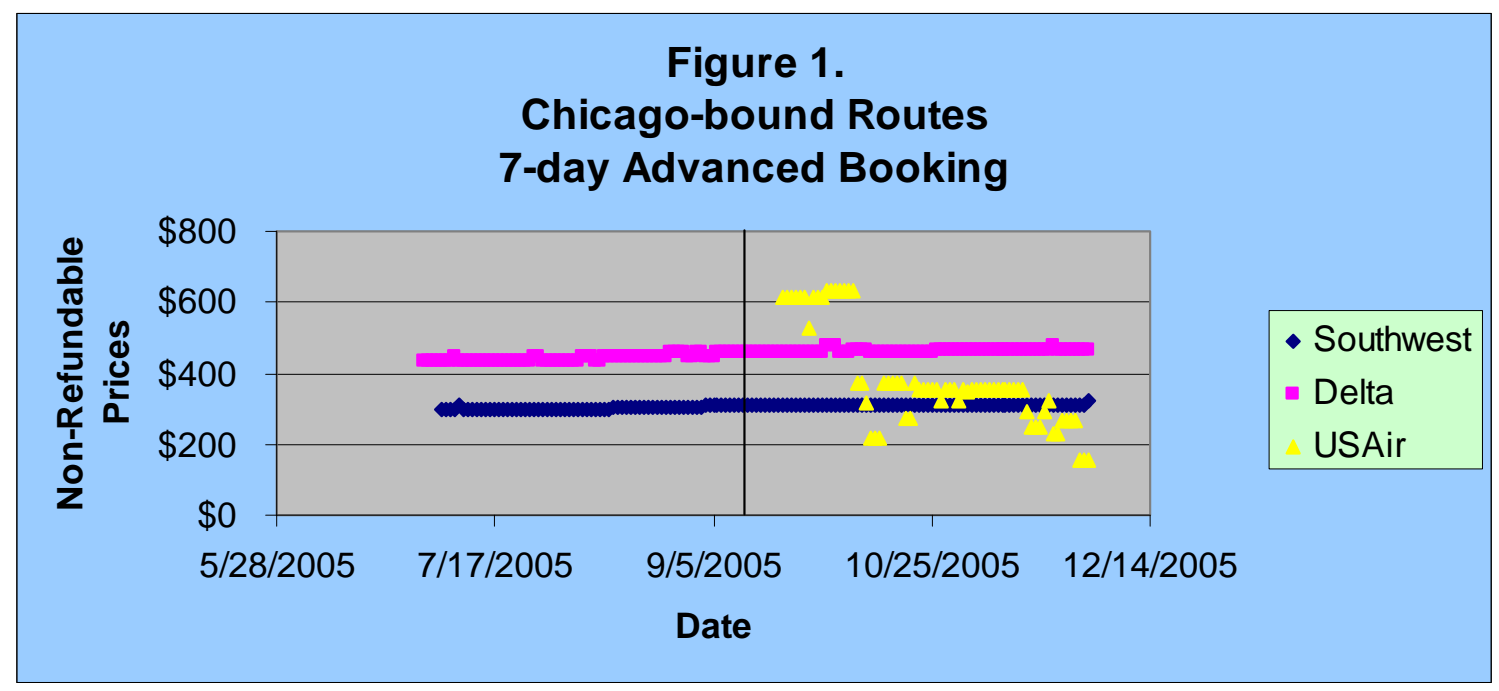



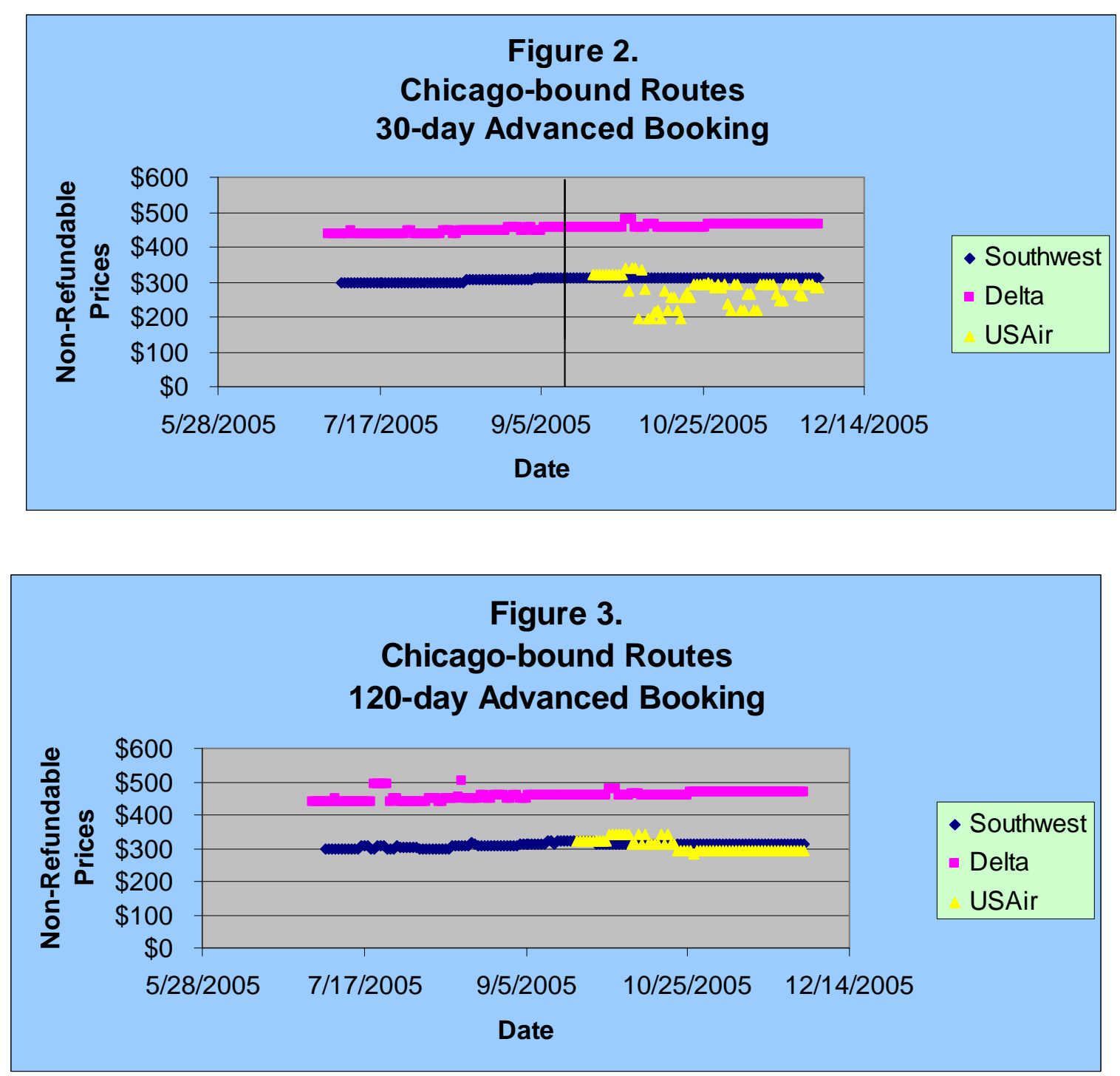
Table 1. Chicago-bound Routes: Average Adjusted Prices

\begin{tabular}{|c|c|c|c|c|c|}
\hline & Total & Pre-9/14/05 & Post-9/14/05 & Change & $\begin{array}{l}\text { Post-event } \\
\text { Log Change }\end{array}$ \\
\hline \multicolumn{6}{|c|}{ Panel A. 7-day Advanced Booking } \\
\hline Southwest & $\begin{array}{c}\$ 307.67 \\
(294.06-321.28)\end{array}$ & $\begin{array}{c}\$ 302.21 \\
(290.11-314.31)\end{array}$ & $\begin{array}{c}\$ 312.78 \\
(310.47-315.09)\end{array}$ & $3 \%$ & $0.04 \%$ \\
\hline Delta & $\begin{array}{c}\$ 453.62 \\
(430.61-476.63)\end{array}$ & $\begin{array}{c}\$ 444.27 \\
(428.82-459.72)\end{array}$ & $\begin{array}{c}\$ 462.85 \\
(451.17-474.53)\end{array}$ & $4 \%$ & $0.03 \%$ \\
\hline USAir & & $\mathrm{n} / \mathrm{a}$ & $\begin{array}{c}\$ 385.98 \\
(104.51-667.45) \\
\end{array}$ & & $-1.94 \%$ \\
\hline \multicolumn{6}{|c|}{ Panel B. 30-day Advanced Booking } \\
\hline Southwest & $\begin{array}{c}\$ 307.58 \\
(293.71-321.45)\end{array}$ & $\begin{array}{c}\$ 301.90 \\
(289.76-314.04)\end{array}$ & $\begin{array}{c}\$ 312.90 \\
(312.90-312.90)\end{array}$ & $4 \%$ & $0.00 \%$ \\
\hline Delta & $\begin{array}{c}\$ 453.53 \\
(430.93-476.13) \\
\end{array}$ & $\begin{array}{c}\$ 444.27 \\
(428.82-459.72) \\
\end{array}$ & $\begin{array}{c}\$ 462.46 \\
(451.16-473.76) \\
\end{array}$ & $4 \%$ & $0.03 \%$ \\
\hline USAir & & $\mathrm{n} / \mathrm{a}$ & $\begin{array}{c}\$ 275.07 \\
(195.25-354.89) \\
\end{array}$ & & $-0.17 \%$ \\
\hline \multicolumn{6}{|c|}{ Panel C. 120-day Advanced Booking } \\
\hline Southwest & $\begin{array}{c}\$ 309.08 \\
(294.31-323.85) \\
\end{array}$ & $\begin{array}{c}\$ 303.54 \\
(290.47-316.61) \\
\end{array}$ & $\begin{array}{c}\$ 314.26 \\
(307.91-320.61) \\
\end{array}$ & $4 \%$ & $0.00 \%$ \\
\hline Delta & $\begin{array}{c}\$ 456.07 \\
(429.55-482.59) \\
\end{array}$ & $\begin{array}{c}\$ 448.95 \\
(418.34-479.56) \\
\end{array}$ & $\begin{array}{c}\$ 462.59 \\
(451.31-473.87) \\
\end{array}$ & $3 \%$ & $0.03 \%$ \\
\hline USAir & & $\mathrm{n} / \mathrm{a}$ & $\begin{array}{c}\$ 306.29 \\
(269.15-343.43) \\
\end{array}$ & & $-0.14 \%$ \\
\hline
\end{tabular}

From Table 1, Panel A presents the average ticket prices 7-days before departure, Panel B presents the ticket prices 30-days before departure, and Panel $\mathrm{C}$ presents the ticket prices 120-days before departure. With each average we also report (in parentheses below the average) the lower and upper bounds of the 95\% confidence interval around the average. The second column presents data for the total sample, column three presents data for the sample prior to the bankruptcy date (i.e. the event date) of September 14, 2005 and column four presents data after this date. The fifth column shows the percentage change in the price mean from before to after the event and the last column presents the average log-change of daily prices after the event.

Southwest ticket prices from its hub (Phoenix) to Chicago suggest a consistent price strategy across our sample period. That is, Southwest's ticket prices are fairly stable (with a positive drift of $3 \%$ to $4 \%$ ) across the sample period with no apparent response to either bankruptcy event. Table 3 suggests that prices paid for jet fuel increased, on average, about $2 \%$ across the sample period. This suggests that the positive drift in Southwest's price is consistent with increasing costs and is not a response to Delta's bankruptcy. 
Table 3. Monthly Jet Fuel Prices Paid

\begin{tabular}{|l|c|c|c|c|c|c|}
\hline Type & June & July & August & September & October & November \\
\hline NYH & $\$ 168.5$ & $\$ 168.6$ & $\$ 190.2$ & $\$ 217.8$ & $\$ 214.4$ & $\$ 174.1$ \\
\hline USGC & $\$ 165.4$ & $\$ 166.5$ & $\$ 187.4$ & $\$ 223.2$ & $\$ 239.8$ & $\$ 169.8$ \\
\hline LOS & $\$ 172.2$ & $\$ 175.3$ & $\$ 202.7$ & $\$ 207.9$ & $\$ 201.7$ & $\$ 173.7$ \\
\hline Average & $\$ 168.7$ & $\$ 170.1$ & $\$ 193.5$ & $\$ 216.3$ & $\$ 218.6$ & $\$ 172.5$ \\
\hline Log-Change & & $.83 \%$ & $12.89 \%$ & $11.14 \%$ & $1.06 \%$ & $-23.68 \%$ \\
\hline
\end{tabular}

Delta's prices from its Atlanta hub to Chicago are substantially above Southwest's (the 95\% confidence intervals do not overlap) for each advanced booking period, even though its flight is less than one-half of the distance and therefore should be less costly. We find no evidence that Delta lowered its prices to Chicago around its bankruptcy filing. However, our data does not extend back far enough to include the period before bankruptcy filing where Borenstein and Rose (1995) find price decreases. We see a positive drift in Delta's prices with the size of the drift being similar to Southwest's positive drift in ticket prices. Again, we suggest that this is consistent with the increase in the cost of jet fuel across our sample period and therefore, unrelated to Delta entering bankruptcy.

USAir exited bankruptcy with prices to Chicago from its Charlotte hub that are similar to Southwest's (both economically and statistically) even though its flight is less than one-half the distance. However, for the most part, USAir prices are substantially less than Delta on flights of similar length. (Note 2) This is consistent with a business exiting bankruptcy with lower costs and lower cost uncertainty. We also note that USAir is the only airline in our sample that actively manages prices across the advanced booking periods. That is, Southwest and Delta maintain consistent prices across booking periods while USAir starts at an average of \$306 with 120-day advance, drops to \$275 with 30-day advance, and increases to $\$ 312$ with 7-day advance. USAir's price behavior is consistent with working down the demand schedule to maximize the number of seats sold on each flight and then squeezing the last-minute purchasers when supply is limited. This is a more aggressive pricing strategy and is consistent with a firm trying to re-capture market share after existing bankruptcy.

Figures 4-6 and Table 2 present ticket prices for the Orlando-bound route of all three carriers and all three advanced booking time periods, adjusted for outliers. The descriptions in Table 2 are identical to Table 1 . Southwest continues to show relative stable prices with a positive drift, although the drift is larger on its Orlando route than its Chicago route. Again, the price increases are likely related to cost increases and the figures show a noticeable price increase in early September when Table 3 shows a large increase in the prices paid for jet fuel. 


\section{Macrothink}
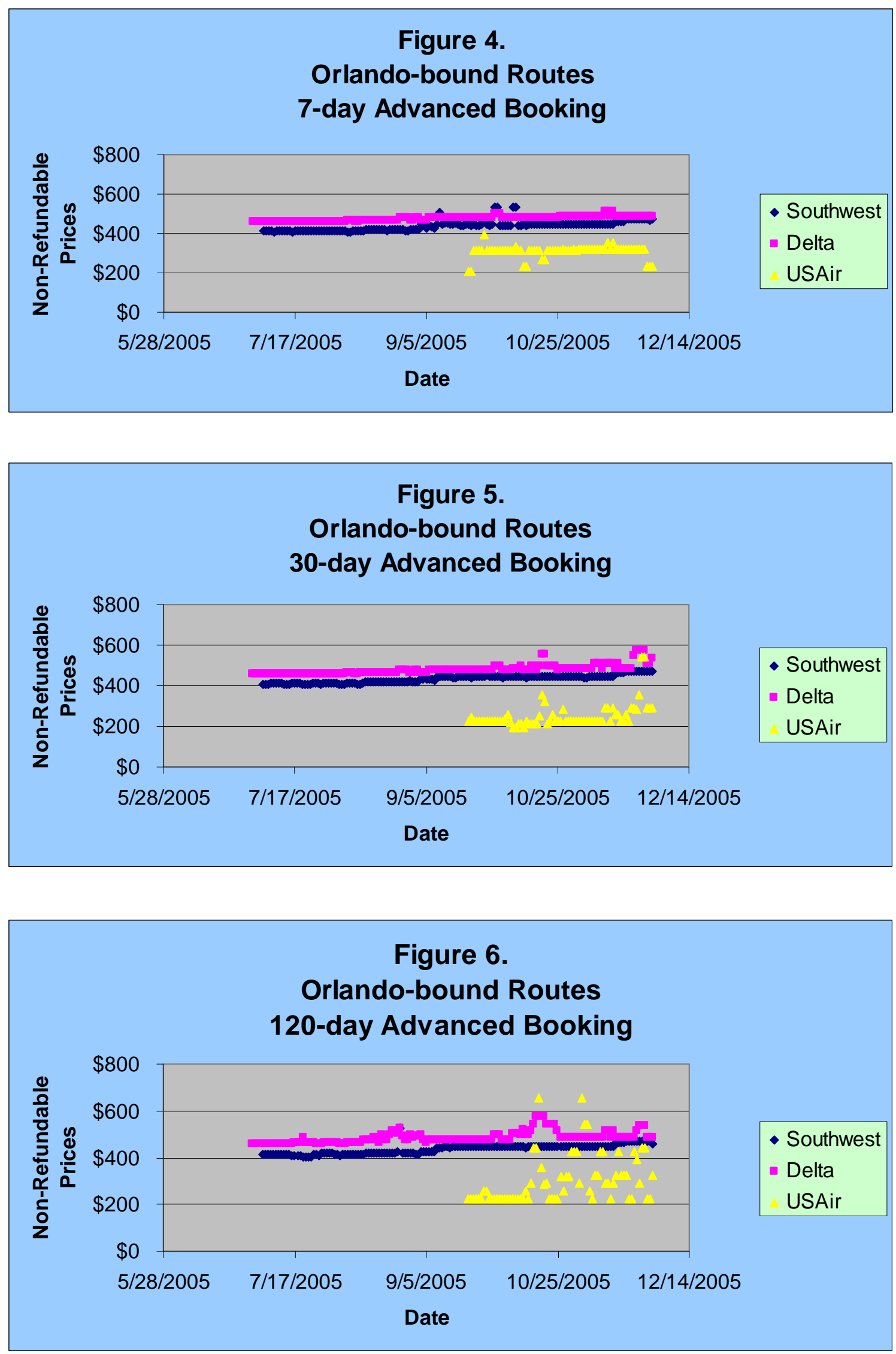
Table 2. Orlando-bound Routes: Average Adjusted Prices

\begin{tabular}{|c|c|c|c|c|c|}
\hline & Total & Pre-9/14/05 & Post-9/14/05 & Change & $\begin{array}{l}\text { Post-event } \\
\text { Log Change }\end{array}$ \\
\hline \multicolumn{6}{|c|}{ Panel A. 7-day Advanced Booking } \\
\hline Southwest & $\begin{array}{c}\$ 437.55 \\
(387.14-487.96)\end{array}$ & $\begin{array}{c}\$ 419.63 \\
(390.02-449.24) \\
\end{array}$ & $\begin{array}{c}\$ 454.30 \\
(412.16-496.44)\end{array}$ & $8 \%$ & $0.07 \%$ \\
\hline Delta & $\begin{array}{c}\$ 474.23 \\
(449.74-498.72) \\
\end{array}$ & $\begin{array}{c}\$ 463.87 \\
(448.21-479.53) \\
\end{array}$ & $\begin{array}{c}\$ 483.55 \\
(467.55-499.55) \\
\end{array}$ & $4 \%$ & $0.03 \%$ \\
\hline USAir & & $\mathrm{n} / \mathrm{a}$ & $\begin{array}{c}\$ 309.54 \\
(246.95-372.13)\end{array}$ & & $0.19 \%$ \\
\hline \multicolumn{6}{|c|}{ Panel B. 30-day Advanced Booking } \\
\hline Southwest & $\begin{array}{c}\$ 434.21 \\
(402.60-465.82)\end{array}$ & $\begin{array}{c}\$ 418.00 \\
(396.26-439.74) \\
\end{array}$ & $\begin{array}{c}\$ 449.37 \\
(429.74-469.00)\end{array}$ & $8 \%$ & $0.07 \%$ \\
\hline Delta & $\begin{array}{c}\$ 480.73 \\
(431.39-530.07) \\
\end{array}$ & $\begin{array}{c}\$ 463.87 \\
(448.21-479.53) \\
\end{array}$ & $\begin{array}{c}\$ 495.83 \\
(445.28-546.38) \\
\end{array}$ & $7 \%$ & $0.15 \%$ \\
\hline USAir & & n/a & $\begin{array}{c}\$ 241.73 \\
(172.66-310.80) \\
\end{array}$ & & $0.36 \%$ \\
\hline \multicolumn{6}{|c|}{ Panel C. 120-day Advanced Booking } \\
\hline Southwest & $\begin{array}{c}\$ 435.42 \\
(395.69-475.15)\end{array}$ & $\begin{array}{c}\$ 419.80 \\
(387.85-451.75) \\
\end{array}$ & $\begin{array}{c}\$ 450.02 \\
(431.79-468.25) \\
\end{array}$ & $7 \%$ & $0.05 \%$ \\
\hline Delta & $\begin{array}{c}\$ 486.41 \\
(435.85-536.97) \\
\end{array}$ & $\begin{array}{c}\$ 471.91 \\
(441.16-502.66) \\
\end{array}$ & $\begin{array}{c}\$ 498.43 \\
(445.27-551.59) \\
\end{array}$ & $6 \%$ & $0.03 \%$ \\
\hline USAir & & n/a & $\begin{array}{c}\$ 287.86 \\
(123.38-452.34) \\
\end{array}$ & & $0.52 \%$ \\
\hline
\end{tabular}

Delta's ticket prices continue to be above Southwest's prices even though its flight to Orlando from its Atlanta hub is less than one-fourth the distance of Southwest's flight to Orlando from Phoenix. (Note 3) Delta's prices also show a positive drift that is similar in magnitude to Southwest's drift. Again, this does not appear to be related to Delta's bankruptcy, but instead to increasing fuel prices.

USAir continues to aggressively price its tickets to actively compete for market share. We see that USAir prices are substantially less than Delta's to Orlando on flights of similar distance, which is again consistent with USAir exiting bankruptcy with lower costs and lower cost uncertainty. (Note 4) We again see that USAir works along the demand schedule with 120 -day books at $\$ 288$, 30-day bookings at $\$ 242$, and 7-day bookings at $\$ 310$.

Finally, we see that the price increases for Southwest and Delta are almost twice as large on flights to Orlando than on flights to Chicago. We suggest this reflects different pricing by airlines on vacation vs. business routes. It appears that vacation travelers (flights to Orlando) are more locked into time and destination than business travelers (flights to Chicago), so airlines more aggressively pass-on cost increases to vacation travelers. 


\section{Concluding Remarks}

We explore whether airline ticket pricing strategies change in response to bankruptcy events. First, we find that Southwest (our proxy for a financial healthy airline) does not respond to bankruptcy events. This finding is counter to the findings in Borenstein and Rose (1995). Second, we find that Delta (our proxy for airlines entering bankruptcy) does not change its pricing strategy in the near-term around the bankruptcy filing, which is consistent with previous empirical results. Finally, we find that USAir (our proxy for airlines exiting bankruptcy) prices its tickets aggressively in an apparent attempt to recapture market share. This result is consistent with cost levels and cost uncertainties declining during bankruptcy such that when the airline exists bankruptcy it can aggressively price its tickets to capture market share.

\section{Acknowledgment}

We would like to gratefully acknowledge the excellent data collection and research assistance provided by Kathy Beard and Matt Eitel.

\section{References}

Alderson, Michael, and Brian L. Betker. (1999). Assessing Postbankruptcy Performance: An Analysis of Reoganized Firms’ Cash Flows. Financial Management, 28, 68-82.

Borenstein, Severin and Nancy L. Rose. (1995). Bankruptcy and Pricing Behavior in U.S. Airline Markets. The American Economic Review, 85, 397-402.

Busse, Meghan. (2002). Firm Financial Condition and Airline Price Wars. RAND Journal of Economics, 33, 298-318.

Delta Cuts Deep in Push to Become Low-Cost Airline. (2005). Wall Street Journal (Eastern edition), September 23, pg. A13.

Eberhart, Allan, Reena Aggarwal and Edward Altman. (1999). The Equity Performance of Firms Emerging From Bankruptcy. Journal of Finance, 54, 1855-1868.

Hofer, Christian, Martin E. Dresner and Robert J. Windle. (2005). Financial distress and US airline fares. Journal of Transport Economics and Policy, 39, 323-340.

Hofer, Christian, Martin E. Dresner and Robert J. Windle. (2009). The impact of airline financial distress on US air fares: A contingency approach. Transportation Research Part E: Logistics and Transportation Review, 45, 238-249.

Sturm, Ray R., and Drew B. Winters. (2009). The Pricing of Embedded Put Options in U.S. Air Fares. Journal of Economics \& Finance, 33, 376-392.

\section{Note}

Note 1. We see, after filing bankruptcy on September 14 2005, Delta Air Lines immediately began pursuing the discharge of their pension obligations as well as reducing their labor costs via salary concessions and employment terminations (Wall Street Journal, 2005). 


\section{Macrothink

Note 2. The USAir price averages are economically less than Delta's price averages with the smallest dollar difference at $\$ 76.87$ on 7-day advanced bookings. However, the 95\% confidence interval on the 7-day prices overlaps due to an unusually large standard deviation on the USAir prices. The confidence intervals on 30-day and 120-day advanced bookings do not overlap.

Note 3. The difference is economical (around 10\% more on flights $1 / 4$ of the length) but not statistically (eight of nine confidence intervals overlap).

Note 4. The difference is economical (about $40 \%$ to $50 \%$ less) and statistically (95\% confidence intervals on 7-day and 30-day do not overlap, but 120-day confidence interval does overlap). The $90 \%$ confidence interval on the 120 -day tickets does not overlap. 